\title{
The David-And-Goliath-esque Problematic of "Unfair Advantage" in Trade Mark Law: Is the EU Moving Towards a Categorical Protection of Famous Brands?
}

\author{
Heather Taylor
}

Accepted: 2 September 2021 / Published online: 17 September 2021

(C) The Author(s) 2021

\begin{abstract}
The extended protection of trade marks with a reputation is losing its "exceptional" character, making way for an almost categorical bar to the registration of any competing sign; indeed, the "unfair advantage" requirement appears to have been confounded with that of similarity. Certainly, trade marks are recognized as a legitimate restriction of the freedom of commerce and, arguably, in principle, competitors can and should invest their own efforts into conceiving and promoting an original sign under which they can market their goods and services. Nevertheless, trade mark law, insofar as it protects the investment function of a reputed mark, does not for as much shield the proprietor from all competition, even if this means that he must work harder in order to preserve this reputation. Indeed, the use of a similar sign is sometimes deemed to be ineluctable, where the applicant demonstrates that he cannot reasonably be required to abstain from using such a sign as, for example, it would be made necessary for the marketing of his products. This is especially true where the sign makes use of descriptive terms or elements in order to indicate the type of goods or services offered by the applicant under the mark applied for. This paper aims to critically discuss the most recent EU and UK jurisprudence on "unfair advantage" in the context of trade mark registration and infringement, focussing primarily on the components of this EU creation and how they are interpreted by courts on both a national and EU level.
\end{abstract}

Keywords Reputation - Substitutes - Unfair advantage - Economic behaviour · Parasitism - Brexit

\footnotetext{
H. Taylor $(\bowtie)$

LL.M., Trinity College Dublin, Dublin, Ireland e-mail: taylorhe@tcd.ie
} 


\section{Overview}

It is now well recognized that trade marks with a reputation are afforded "extensive" protection ${ }^{1}$ in the sense that a mark that secures a reputation is afforded protection - by virtue of the "intrinsic" economic added value thereby acquired that transcends the category of goods or services for which it has been registered. ${ }^{2}$

If the "essential function" of the trade mark is that of assuring commercial origin, thereby enabling consumers to freely make their choice by distinguishing, without any possibility of confusion, the goods or services of one undertaking from those of another, ${ }^{3}$ this is not the function with which the provisions on reputed marks are concerned. ${ }^{4}$

Indeed, a trade mark also serves as a means of capturing and retaining customers through the association of the registered mark with "particular qualities or characteristics of the goods or services it designates, or the images and sensations it projects," 5 for example, pertaining to a certain lifestyle, sought-after by a certain demographic. ${ }^{6}$ This is the so-called "investment function" that serves, namely, to obtain and maintain a reputation among consumers, ${ }^{7}$ considered by some as a mark's "primary purpose." 8 The aim is therefore to protect, not the general public (from confusion), but the interests of the trade mark proprietor himself. ${ }^{9}$

In this sense, the reinforced protection of marks with a reputation belongs to the businesses that can afford to build one. ${ }^{10}$ To be sure, this requires considerable

\footnotetext{
1 Premier Brands UK Ltd v. Typhoon Europe Ltd and Anor [2000] EWHC 1557 (Ch), Neuberger J; Case C-65/12 Leidseplein Beheer BV and Hendrikus de Vries v. Red Bull GmbH [2014] EU:C:2014:49, para. 46. See also TMD (infra note 20), Recital 10.

2 Case C-292/00 Davidoff \& Cie SA and Zino Davidoff SA v. Gofkid Ltd [2003] EU:C:2003:9, paras. 25-30; Case T-215/03 SIGLA SA v. OHIM [2007] EU:T:2007:93 (VIPS), para. 35; Joined Cases C-720/18 and C-721/18 Ferrari SpA v. DU [2020] EU:C:2020:854, paras. 41-44. See also Alice L. Blythe (2012), p. 754 .

3 Datacard Corporation v. Eagle Technologies Ltd [2011] EWHC 244 (Pat), para. 263 per Arnold J; Case C-371/18 Sky plc v. SkyKick UK Ltd [2020] EU:C:2020:45, para. 74. See also TMA 1994 (infra note 21), Sec.1(1)(b); TMD (infra note 20), Art. 3(a) and Recital 16; EUTMR (infra note 22), Art. 4(a) and Recital 11.

4 Cf. European Union Intellectual Property Office (EUIPO), "Guidelines for Examination of European Union Trade Marks - Part C: Opposition” (March 2021) (EUIPO Guidelines), Sec. 5, 1134.

5 VIPS (supra note 2), para. 35. See also Case C-487/07 L'Oréal SA and Others v. Bellure NV and Others [2009] EU:C:2009:378, para. 58; Case C-323/09 Interflora Inc v. Marks \& Spencer plc [2011] EU:C:2011:604, para. 38.

6 See also Opinion of Advocate General Sharpston in Intel (C-252/07) [2008] EU:C:2008:370, point 8.

7 Case C-323/09 Interflora Inc v. Marks \& Spencer plc [2011] EU:C:2011:604, paras. 60-61.

${ }^{8}$ Frank Schechter (1927), p. 822.

9 See Lotte Anemaet (2020), p. 189; EUIPO Guidelines (supra note 4), Sec. 5, 1134. See also Opinion of Advocate General Jääskinen in Interflora (C-323/09) [2011] EU:C:2011:173, point 64.

${ }^{10}$ Cf. Robert M. Kunstadt (2008), p. 453.
} 
amounts of promotional and marketing expenditure ${ }^{11}$ which, apparently, would warrant protection as such. ${ }^{12}$

In principle, reputation, unlike distinctiveness, cannot be intrinsic to a mark; rather it is acquired vis-à-vis the goods or services it designates and by dint of the use made of it by its proprietor. ${ }^{13}$ As such, it is measured quantitatively, as a "degree of knowledge" of the mark amongst the relevant public; ${ }^{14}$ that is, the general public regarding repeat-purchase, mass-consumption products, or rather specialized or professional users where the goods or services have a specific purpose or belong to a niche market. ${ }^{15}$

For as much, proving reputation is "not a particularly onerous requirement": ${ }^{16}$ it is a question of "proportion rather than absolute numbers," 17 satisfied where a "substantial part" of the relevant public of the Member State in which registration is applied for, ${ }^{18}$ or, in the case of an EU trademark, in the EU - in which case a reputation amongst at least a "commercially significant" part of the relevant public in a single Member State may suffice. ${ }^{19}$

Article 5(3)(a) of the Trade Mark Directive, ${ }^{20}$ and its equivalents in the UK Trade Marks Act $1994^{21}$ and the European Union Trade Mark Regulation, ${ }^{22}$ set out the relative grounds for refusal or invalidity of the registration of a later mark using a sign that is identical or similar to a registered mark with a reputation.

In order to benefit from this extended protection, the proprietor must adduce evidence fulfilling several cumulative conditions - in addition to the existence of a

\footnotetext{
11 Ibid. 454. See also VIPS (supra note 2), para. 35; EUIPO Guidelines (supra note 4), Sec. 5, 1191.

12 VIPS (supra note 2), para. 35; Interflora (supra note 7), paras. 60-61. See also Schechter (supra note 8); Ilanah Simon Fhima (2012), p. 499.

13 Sazerac Brands LLC v. Liverpool Gin Distillery Ltd [2020] EWHC 2424 (Ch), para. 33 per Fancourt J. See also EUIPO Guidelines (supra note 4), Sec. 5, 1139 and 1188.

14 Case C-375/97 General Motors Corporation v. Yplon SA [1999] EU:C:1999:408, para. 23; Case C-301/07 PAGO International GmbH v. Tirolmilch registrierte GmbH [2009] EU:C:2009:611, para. 21. See also EUIPO Guidelines (supra note 4), Sec. 5, 1139.

15 General Motors (supra note 14), paras. 24 and 26; Sazerac (supra note 13), para. 19 per Fancourt J. See also EUIPO Guidelines (supra note 4), Sec. 5, 1141-1142.

${ }^{16}$ W3 Ltd v. Easygroup Ltd \& Anor [2018] EWHC 7 (Ch), para. 291 per Arnold J; Sazerac (supra note 13), para. 33 per Fancourt J.

17 Burgerista Operations GmbH v. Burgista Bros Limited [2018] EWHC (IPEC), para. 69 per Judge Hacon. See also EUIPO Guidelines (supra note 4), Sec. 5, 1141.

18 General Motors (supra note 14), para. 28.

19 PAGO International (supra note 14), paras. 27-29; Case C-125/14 Iron \& Smith kft v. Unilever NV [2015] EU:C:2015:539, paras. 20 and 30; Sazerac (supra note 13), para. 37.

${ }^{20}$ Directive (EU) 2015/2436 of the European Parliament and of the Council of 16 December 2015 to approximate the laws of the Member States relating to trade marks [2015] OJ L336/1 (TMD).

21 Trade Marks Act 1994 (as amended by The Trade Marks (Amendment etc.) (EU Exit) Regulations 2019 (SI 2019/269)) (TMA 1994), Secs. 5(3) and 5(3A).

22 Regulation (EU) 2017/1001 of the European Parliament and of the Council of 14 June 2017 on the European Union trade mark [2017] OJ L154/1 (EUTMR), Art. 8(5).
} 
reputation. ${ }^{23}$ Logically, the sign for which registration is sought must be identical or at least similar to the earlier mark with a reputation - in terms of shared visual, aural or conceptual elements - to the extent that the average consumer would establish a link between them. ${ }^{24}$

Considering that the investments expended on increasing brand awareness and marketing are largely influential as regards the finding of reputation, ${ }^{25}$ and that an exceptional and global reputation prejudges a link between the conflicting marks due to the heightened temptation to exploit the earlier mark's appeal, ${ }^{26}$ big brands tend to benefit from a lighter burden of proof.

Most importantly, the use of this sign must be, at least, likely to give rise to one of the three distinct types of "injury" enumerated by the aforementioned texts, of which the taking of unfair advantage, also referred to as "free-riding" or "parasitism.",27

Certainly, the specific subject matter of trade marks is defined as, in terms of the proprietor's rights, the exclusivity of use of the trade mark ${ }^{28}$ and, therefore, the protection "against competitors wishing to take advantage" of that mark. ${ }^{29}$

For as much, these provisions do not enable the proprietor of a reputed mark to prevent the use of any sign bearing similarity to his mark, but solely that which would "exploit [...] [its] distinctive character or repute." 30

Firstly, an observation must be made: the burden of proof for establishing the risk of unfair advantage is comparably lighter than in the cases of dilution stricto sensu, otherwise known as "blurring" - i.e., the causing of harm to the distinctive character of the earlier mark, established where the use of the mark applied for would affect the former's capacity to arouse immediate association with the goods for which it is registered and used - or of "tarnishment" - i.e., whereby the proprietor of the earlier mark must prove that the use of the mark applied for would

${ }^{23}$ Case C-564/16 P Puma SE v. EUIPO [2018] EU:C:2018:509, para. 54. See also Comic Enterprises v. 20th Century Fox [2016] EWCA Civ 41, para. 111 per Kitchen LJ; Red Bull GmbH v. Big Horn UK Limited \& Others [2020] EWHC 124 (Ch), para. 21 per Bacon DJ.

24 Case C-408/01, Adidas-Salomon AG v. Fitnessworld Trading Ltd [2003] EU:C:2003:582, paras. 28-29; Joined Cases C-85/16 P and C-86/16 P Kenzo Tsujimoto v. EUIPO [2018] EU:C:2018:349, para. 56. See also Specsavers International Healthcare Ltd and Ors v. Asda Stores Ltd [2012] EWCA Civ 24, para. 120 per Kitchin LJ; Comic Enterprises (supra note 23), para. 110 per Kitchen LJ.

25 EUIPO Guidelines (supra note 4), Sec. 5, 1161-1163. See also Case C-100/11 P Helena Rubinstein SNC and L'Oréal SA v. OHIM [2012] EU:C:2012:285, paras. 65-66.

${ }^{26}$ Case T-677/18 Galletas Gullón, SA v. EUIPO [2020] EU:T:2020:229 (Oreo), paras. 116-117. See also EUIPO Guidelines (supra note 4), Sec. 5, 1193.

27 Case C-487/07 L'Oréal SA and Others v. Bellure NV and Others [2009] EU:C:2009:378, paras. 38-41; Sazerac (supra note 13), para. 40 per Fancourt J.

28 See TMA 1994 (supra note 21), Sec. 9(1); TMD (supra note 20), Art. 10(1); EUTMR (supra note 22), Art. 9(1).

29 See Case 16-74 Centrafarm BV and Adriaan de Peijper v. Winthrop BV [1974] EU:C:1974:115, para.

8; Case 102/77 Hoffmann-La Roche \& Co. AG v. Centrafarm Vertriebsgesellschaft Pharmazeutischer Erzeugnisse mbH [1978] EU:C:1978:108, para. 7. Cf. Fhima (supra note 12), p. 507; Michal Bohaczewski (2020), p. 857.

30 Premier Brands UK Ltd v. Typhoon Europe Ltd and Anor [2000] EWHC 1557 (Ch), Neuberger J. See TMA 1994 (supra note 21), Sec. 5(3); TMD (supra note 20), Art. 5(3)(a); EUTMR (supra note 22), Art. $8(5)$. 
cause detriment to the repute of his mark to the extent that its power of attraction would, thereby, be diminished. ${ }^{31}$

Indeed, the concept of unfair advantage does not entail that the use of the mark applied for would damage the earlier mark with a reputation, but simply that an advantage would be unduly derived by the applicant. ${ }^{32}$ As such, it is more a question of dilution of the proprietor's investments into building his brand than of the mark per se.

Subsequently, the risk of such an unfair advantage being taken must be assessed with regard to the average consumers of the goods or services for which registration of the later mark is sought, reasonably informed and attentive. ${ }^{33}$

As such, the concept of unfair advantage confers a sort of "extensive extended" protection (Sect. 2), which has drawn criticism from certain commentators as regards its potential adverse effects on competition, and with especial concern for consumers and their right to alternatives (Sect. 3). ${ }^{34}$

\section{The Double-Edged Sword of "Unfair Advantage"}

The provisions concerning the relative grounds for refusal or invalidity are, logically, in the conditional as, a priori, in the context of opposition proceedings, the sign has not yet been used in the course of trade. Subsequently, the proprietor need not establish that actual and concrete unfair advantage has been taken. On the contrary, he need only prove that the likelihood of such an advantage occurring due to the use of the sign is serious and real, in the sense that it is foreseeable and not merely hypothetical, in view of the normal practice in the relevant commercial sector. $^{35}$

The fact that the earlier mark enjoys a substantial reputation is not conclusive as to the existence of such a risk. ${ }^{36}$ However, the existence of certain legal presumptions - which rely on the premise that "a very strong reputation is both

\footnotetext{
31 Cf., for a detailed discussion, Case T-480/12 The Coca-Cola Company v. OHIM [2014] EU:T:2014:1062, para. 83.

32 L'Oréal SA v. Bellure NV (supra note 27), paras. 41 and 43. See also Opinion of Advocate General Jääskinen in Interflora (supra note 9), point 53.

33 Case C-252/07 Intel Corporation Inc v. CPM United Kingdom Ltd [2008] EU:C:2008:655, para. 36; Case C-320/07 P Antartica Srl v. OHIM [2009] EU:C:2009:146, para. 48. See also Sky Plc v. Skykick UK Ltd [2018] EWHC 155 (Ch), paras. 274-275 per Arnold J; Red Bull (supra note 23), para. 23 per Bacon DJ. Cf. EUIPO Guidelines (supra note 4), Sec. 5, 1192.

34 See Daniel Klerman (2006), p. 1771; Opinion of Advocate General Jääskinen in Interflora (supra note 9), point 94.

35 See Mastercard International Incorporated v. Hitachi Credit (UK) Plc [2004] EWHC 1623 (Ch), paras. 51 and 54 per Smith J; Intel (supra note 33), para. 38; Rubinstein and L'Oréal (supra note 25), paras. 93 and 95; Case C-383/12 P Environmental Manufacturing LLP v. OHIM [2013] EU:C:2013:741 ("WOLF"), paras. 42-43. See also EUIPO Guidelines (supra note 4), Sec. 5, 1211.

36 Group Lotus Plc and Anor v. 1Malaysia Racing Team SDN BHD and Ors [2011] EWHC 1366 (Ch), para. 252 per Smith J.
} 
easier to harm and more tempting to take advantage of" ${ }^{, 37}$ - albeit rebuttable, would seem to place the odds in favour of the proprietor of a reputed mark.

As such, given that "it is by bringing the mark to mind that it is possible for the unfair advantage to be taken," 38 a stronger and more immediate bringing to mind by virtue of, for example, the exceptional reputation of the earlier mark or pronounced similarity between the marks at issue - presupposes the taking of such an advantage. ${ }^{39}$

\subsection{The Presumption of Advantage: A Change on the Horizon?}

The concept of "unfair advantage" - proclaimed by the UK courts to be "a particular form of unfair competition" 40 - cannot, as the corollary of an extensive protection, be restricted to an exhaustive enumeration of tell-tale signs, but rather must be "applied in a flexible manner on a case-by-case basis." 41

However, it is widely acknowledged that where the applicant, by using a sign at least similar to the mark with a reputation, would benefit commercially from the latter's power of attraction, reputation, image and prestige, there is advantage. ${ }^{42}$

It ensues from the CJEU's ruling in Interflora ${ }^{43}$ that the simple fact that consumers would choose the goods or services offered by a competitor using an identical or similar sign, instead of those of the owner of the reputed mark, would translate as a "real advantage" for the latter.

Very recently, the UK courts seem to have interpreted this as requiring a positive change in the economic behaviour of the competitors' shared consumer base, i.e., where they provide the same goods or services and thus operate on the same market. $^{44}$

Indeed, in the recent Sazerac case, it was stated that proof of, at least, the likelihood of such a change is "sufficient to establish an advantage taken" of the earlier mark with a reputation (but not to establish that the advantage would be unfair), ${ }^{45}$ without for as much constituting a necessary requirement. ${ }^{46}$

\footnotetext{
37 Cf. EUIPO Guidelines (supra note 4), Sec. 5, 1213.

38 Argos Ltd v. Argos Systems Inc [2018] EWCA Civ 2211, para. 83 per Floyd LJ. See also Lionel Bently and Brad Sherman (2014), p. 999.

39 L'Oréal SA v. Bellure NV (supra note 27), para. 44; Intel (supra note 33), para. 67; Iron \& Smith (supra note 19), para. 33; Red Bull (supra note 23), para. 35 per Bacon DJ; PlanetArt LLC v. Photobox Ltd and Anor [2020] EWHC 713 (Ch), para. 36 per HHJ Alexander QC.

${ }^{40}$ Per Arnold J in: Jack Wills Limited v. House of Fraser (Stores) Limited [2014] EWHC 110 (Ch) para. 80; Easygroup (supra note 16), para. 300; Skykick (supra note 33), para. 315.

41 Opinion of Advocate General Mengozzi in L'Oréal (C-487/07) [2009] EU:C:2009:70, point 71.

42 L'Oréal SA v. Bellure NV (supra note 27), para. 49; Leidseplein (supra note 1), para. 52. See also EUIPO Guidelines (supra note 4), Sec. 5, 1188-1189.

43 (Supra note 7), para. 87.

44 See Argos (supra note 38), para. 107 per Floyd LJ.

45 Sazerac Brands LLC v. Liverpool Gin Distillery Ltd [2020] EWHC 2424 (Ch), para. 45 per Fancourt J. Compare with Argos (supra note 38), para. 107 per Floyd LJ.

46 Ibid., with reference to Argos (supra note 38), para. 107 per Floyd LJ.
} 
However, further on in the decision, Justice Fancourt held that the use of the similar sign must be likely to affect the economic behaviour of the average consumer in the relevant public, failing which it cannot be considered that the applicant would obtain an advantage from the association thereby created between the conflicting marks, "unfair or otherwise." 47 Consequently, the proof of a change in economic behaviour would be only one mandatory step out of two in the establishment of an "unfair advantage." 48

Indeed, the very "essence" of taking advantage is that the applicant "must obtain some benefit from the association with [the earlier mark with a reputation], which will manifest itself in the way that consumers in the relevant market act." 49

Traditionally, however, the condition of a change in economic behaviour of the average consumer - which serves to keep the rights of trade mark owners in check by raising the bar of proof ${ }^{50}$ - has only been explicitly required for proving a risk of detriment to the reputed mark. ${ }^{51}$ Besides, such a change can even be held to be implicit in the very concept of taking an unfair advantage, ${ }^{52}$ as it posits the "crosspollination" of the reputed mark's value, and thus inherently of the increase in trade that flows therefrom. ${ }^{53}$

However, it seems as though the UK courts have introduced this requirement through the back door.

Perhaps, this may serve to inject some balance into the provisions on unfair advantage, given that the proprietor of a reputed mark currently has to prove neither confusion as to origin - which presupposes a higher level of similarity between the marks at issue ${ }^{54}$ - nor the existence of harm to his mark or to his economic interests in general. ${ }^{55}$ It remains to be seen whether this requirement will remain, post-Brexit, a UK construction or whether it will explicitly find its way into the case-law of the European courts.

That being so, the UK courts seem to have equally made establishing a likely change in economic behaviour, which is notoriously difficult, easier. As such, according to Alexander QC sitting as Deputy Judge in the PlanetArt case, it is not necessary to demonstrate a direct impact on the economic behaviour of the average

\footnotetext{
47 Ibid. para. 106.

48 Ibid. para. 108.

49 Ibid. para. 93.

${ }^{50}$ Fhima (supra note 12), 514.

51 Intel (supra note 33), paras. 6, 77 and 81, confirmed by Environmental Manufacturing LLP ("WOLF") (supra note 38), paras. 34-41. See also 32Red Plc v. WHG (International) Limited and Others [2011] EWHC 665 (Ch) per Henderson J.

52 Colin Davies (2013), p. 376.

53 See Bently and Sherman (supra note 38), p. 999.

54 Adidas (supra note 24), para. 29; Intel (supra note 33), para. 66; Group Lotus (supra note 36), para. 252 per Smith J.

55 L'Oréal SA v. Bellure NV (supra note 27), para. 43; Sazerac (supra note 45), para. 45 per Fancourt J.
} 
consumer; it suffices to show that the registration of the applicant's mark would cause the proprietor himself to change his behaviour, in that he would feel "obliged to make [his] mark more different from that of a newcomer in order to maintain the same level of recognition," 56 and thus "edge away from the new-comer at some cost" - one thinks of a brand extension - "or devote resources to amplifying its brand message." 57

This seems somewhat overly protective of famous trade mark owners' interests, as increasing investment into one's brand in order to enhance its attractiveness amongst consumers in the fight to survive the entry of new competition is the corollary of a free and open market economy.

Nevertheless, showing that an advantage is, at least, likely to be obtained does not suffice in order to prevent the applicant's sign from being registered. The proprietor of the earlier mark is yet to prove that this advantage would be unfair. ${ }^{58}$

\subsection{A Practical Approach to Expounding "Unfairness"}

An unfair use is one which would "substantially interfere [...] with the proprietor's use of its trade mark to acquire or preserve a reputation capable of attracting consumers and retaining their loyalty," 59 i.e., with the investment function.

It is now widely accepted that "unfair" equates to "without justification."60 More precisely, there is a requirement of "disproportionality" of the advantage likely to be or actually obtained - for example a considerable increase in sales namely in relation to the applicant's own investments (of money, time and effort) into the marketing of his products or services and his failure to compensate the proprietor for the beneficial association created with the latter's reputed mark. ${ }^{61}$ To this the UK Intellectual Property Office (IPO) adds the applicant's aversion of risk, inherent to the creation of an original mark. ${ }^{62}$

Likewise, the heavier the "advertising expenditure or investment in promotion" sacrificed by the proprietor of the earlier reputed mark, the more likely any advantage that may be obtained by the applicant will be deemed disproportionate and illegitimate, and thus to constitute free-riding. ${ }^{63}$

That being said, according to Lord Justice Floyd in Argos - a case concerning the use of a domain name in the context of Google's AdSense programme - the fact that

\footnotetext{
56 PlanetArt LLC v. Photobox Ltd and Anor [2020] EWHC 713 (Ch), para. 179 per HHJ Alexander QC.

57 Ibid. para. 32.

58 Whirlpool Corporation and Ors v. Kenwood Ltd [2009] EWCA Civ 753, para. 136 per Lloyd LJ; Sazerac (supra note 45), para. 107. Fancourt J.

59 Interflora (supra note 7), para. 62. See also Leidseplein (supra note 1), para. 52.

60 See EUIPO Guidelines (supra note 4), Sec. 5, 1194. See also Opinion of Advocate General Jääskinen in Interflora (supra note 9), point 53.

61 L'Oréal SA v. Bellure NV (supra note 27), paras. 41, 49 and 50; Red Bull (supra note 23), para. 36 per Bacon DJ, citing the latter. See also Case T-669/19 Novomatic AG v. EUIPO [2020] EU:T:2020:408, para. 82 .

62 See Case BL O/227/19 Airsorted Limited v. Airbnb, Inc [2019], para. 73 per CJ Bowen as the Appointed Person. Cf. Davies (supra note 52), p. 376.

63 Sazerac (supra note 45), para. 108.
} 
the applicant can avoid benefiting from the advantage resulting from the use of the identical or similar sign to the earlier reputed mark does not, as such, make the advantage obtained or likely to be obtained unfair where it would be unreasonable to expect the applicant "to adopt the least advantageous or most burdensome way" of dealing with the association thereby created between the conflicting marks. ${ }^{64}$

The fact that the existence of a competitor on his market is "irritating" is irrelevant as to whether the advantage is unfair; ${ }^{65}$ the proprietor of a reputed mark is not entitled to a monopoly over all signs identical or similar to his own. ${ }^{66}$

As is true for establishing a link, the unfair nature of the advantage taken is assessed globally, taking into account certain factors such as, inter alia, the distinctiveness of the mark and the strength of its reputation, as well as the degree of similarity between the conflicting marks and the consumer groups and market segments they respectively target. ${ }^{67}$

Notwithstanding, not all advantages are equal.

According to Lord Justice Floyd in Argos, referring to the CJEU's findings in L'Oréal, there is a presumption of a taking of unfair advantage where there is, or is likely to be, "a transfer of the image of the mark or of the characteristics which it projects" to the applicant's goods or services. ${ }^{68}$ Where such a transfer has not taken place, how then is an unfair advantage identified?

Fortunately, the UK courts and the UK IPO have offered some invaluable commentary in this regard.

Firstly, it must be remarked that, if it is true that the "paradigm case" 69 of unfair advantage is where the applicant consciously intends to benefit from the earlier mark's "reputation and goodwill" - the finding of unfair advantage being alas more likely and easier to prove $\mathrm{e}^{70}$ - this subjective factor of bad faith is not required as a condition sine qua non. ${ }^{71}$ As such, proof of the mere "risk" of transfer and the benefits it entails is sufficient, even if this was not the applicant's objective. ${ }^{72}$

An example of such bad faith would be where the applicant unabashedly attempts to imitate an earlier mark with a great reputation or enjoying a highly distinctive

\footnotetext{
$\overline{64}$ Argos (supra note 38), para. 111.

65 Sazerac (supra note 45), para. 110.

66 Ibid.

67 Intel (supra note 33), paras. 67-69; L'Oréal SA v. Bellure NV (supra note 27), para. 44; Skykick (supra note 33), paras. 309 and 314 per Arnold J; Red Bull (supra note 23), paras. 34-35 per Bacon DJ; PlanetArt (supra note 56), para. 36 per HHJ Alexander QC.

68 Argos (supra note 38), paras. 88 and 103 per Floyd LJ referring to L'Oréal SA v. Bellure NV (supra note 27), para. 41. Cf. Frederick W. Mostert and Ludwig Baeumer (1997), p. 62. See also, for a similar opinion, Opinion of Advocate General Mengozzi in Rubinstein and L'Oréal (C-100/11 P) [2012] EU:C:2012:95, point 32.

69 Sazerac (supra note 45), para. 104 per Fancourt J.

70 Per Arnold J in: Jack Wills (supra note 40), para. 80; Skykick (supra note 33), para. 315; Easygroup (supra note 16), para. 300. See also Specsavers (supra note 24), para. 154 per Kitchin J. Cf. EUIPO Guidelines (supra note 4), Sec. 5, 1194.

71 VIPS (supra note 2), para. 40; Jack Wills (supra note 40), para. 80 per Arnold J.

72 Ibid. Cf. EUIPO Guidelines (supra note 4), Sec. 5, 1193-1194.
} 
character, ${ }^{73}$ or, according to the UK IPO, where the applicant "could have chosen any [other] trade mark under which to conduct its services" or sell its goods. ${ }^{74}$

Likewise, it would appear as though the UK IPO instates a presumption of bad faith where the applicant, presuming that he is a direct competitor of the owner of the earlier mark with a reputation, has a business model "based upon" targeting the latter's customers, such that it is evident that the use of the identical or similar sign would be "highly likely" to induce these consumers to use his services or purchase his products "than might otherwise have been the case." 75

Notwithstanding, certain Advocates General have stated that, although not irrelevant, the extent of the advantage to the applicant and the potential loss to the proprietor of the reputed mark "in terms of the luring-away of customers [...] must carry less weight than other factors in determining whether the advantage is unfair." 76

Most interestingly, the UK courts have recently found that simply because a competitor intends on copying the successful marketing or packaging strategies of a business - without for as much creating a risk of confusion as to origin - and subsequently risks being sued by the proprietor of the reputed mark, does not mean that he thereby actively intends to benefit from its reputation and goodwill; ${ }^{77}$ ergo, such conduct may fall within the so-called "ambit of fair competition". ${ }^{78}$

This is the distinction between an advantage per se and an advantage that is unfair. In other words, "the concept of taking advantage implies something deliberately done," to the exclusion of recklessness or negligence: ${ }^{79}$ as such, a trader should not be punished for choosing to "live dangerously." 80 This is best exemplified in the case of alternatives (See 3.2).

Indeed, it is settled case-law, at least within the UK, that an "economic" advantage cannot alone suffice to prove the unfair nature of the latter, ${ }^{81}$ whether this advantage was actively sought after or just a fortunate side-effect.

One can only commend this conclusion as, logically, in the world of business, the only advantages of interest to undertakings are those of a commercial nature. Likewise, this type of advantage is, arguably, so easy to establish that to decide

\footnotetext{
73 See L'Oréal SA v. Bellure NV (supra note 27), paras. 48-49. See also Whirlpool (supra note 58), para. 111 per Lloyd LJ; Interflora (supra note 7), para. 91.

74 Case BL O/227/19 Airsorted Limited v. Airbnb, Inc [2019], para. 76 per C J Bowen as the Appointed Person.

75 Ibid. paras. 75-76.

76 See, for example, Opinion of Advocate General Mengozzi in L'Oréal (supra note 41), point 76.

77 PlanetArt (supra note 56), paras. 38-39 per HHJ Alexander QC, applying the findings of Kitchin LJ in Specsavers (supra note 24) at para. 115, to the provisions on extended protection for reputed marks; Sazerac (supra note 45), para. 46 per Fancourt J.

78 Interflora (supra note 7), para. 91.

79 Sazerac (supra note 45), para. 46 per Fancourt J.

80 Ibid.

81 Argos (supra note 38), para. 108 per Floyd LJ (with whom Lord Kitchen and Sir Colin Rimer agreed); PlanetArt (supra note 56), para. 35 per HHJ Alexander QC.
} 
otherwise would be to "confer on the [proprietor of the reputed mark] greater rights than [he] already [has]" 82 and, thus, to risk quashing legitimate competition.

\section{Vip Protection for Vibs: The Degree of Exposure to Competition for Famous Brands}

The line that demarcates where unfairness ends and due cause begins is, unfortunately, a blurred one.

Indeed, the so-called "due cause defense" 83 only comes into play once the proprietor of the earlier reputed mark has proved that the use of the sign applied for would take unfair advantage of his mark. ${ }^{84}$ In such uncomplimentary circumstances, it is well-recognized that the applicant will have a harder time showing that the use of the sign applied for would nevertheless be justified. ${ }^{85}$

Certainly, the EU rules on trade marks are aimed "at contributing to the system of undistorted competition." 86 Yet important issues such as free expression, enhancing consumer choice, and free competition preventing unnecessary barriers to trade have not been expressly considered in determining "unfairness." 87

What's more, in most cases, it is the applicant's less reputed, non-brand competitors who will be put at a competitive disadvantage by his use of a sign similar to a reputed mark, ${ }^{88}$ as it is they that do not benefit from the "borrowed" attractiveness of the later mark. ${ }^{89}$

This is not, however, always the case.

\subsection{A Restrictive Interpretation of "Due Cause"}

In principle, the due cause defense is the result of a balance struck by the EU legislator between the interests of the owner of the mark with a reputation and those of the applicant, namely "in using, in the course of trade, such a sign for the purposes of denoting the goods and services that [he] market[s]."90

Notwithstanding, to follow the conclusions of the Advocate General Sharpston in Kenzo, this balance seems to lean rather in favour of the owner of the reputed mark insofar as "more weight" must be given to the extent of the injury caused to him

\footnotetext{
82 Sazerac (supra note 45), para. 104 per Fancourt J.

83 See TMA 1994 (supra note 21), Sec. 5(3); TMD (supra note 20), Art. 5(3)(a); EUTMR (supra note 22), Art. 8(5).

84 Intel (supra note 33), paras. 37 and 39; Iron \& Smith (supra note 19), para. 31; Argos (supra note 38), paras. 120 and 122 per Kitchin LJ.

85 PlanetArt (supra note 56), para. 43 per HHJ Alexander QC.

${ }^{86}$ Case C-206/01 Arsenal Football Club plc v. Matthew Reed [2002] EU:C:2002:651, para. 48; Case C-371/18 Sky plc v. SkyKick UK Ltd [2020] EU:C:2020:45, para. 74

87 Fhima (supra note 12), p. 510; Anemaet (supra note 9), p. 190.

88 Sazerac (supra note 45), para. 108 per Fancourt J.

89 See EUIPO Guidelines (supra note 4), Sec. 5, 1194.

90 Case C-65/12 Leidseplein Beheer BV v. Red Bull GmbH [2014] EU:C:2014:49, paras. 41 and 43; Kenzo (supra note 24), para. 90. See also Comic Enterprises (supra note 23), para. 123 per Kitchin LJ.
} 
than to any apparent due cause that might justify the applicant's use of the identical or similar sign. ${ }^{91}$

To be sure, if the applicant is successful in proving that he has due cause for using his sign, the owner of the mark with a reputation is obliged to tolerate this use. $^{92}$

That being so, due cause cannot be invoked where the applicant simply proposes a mere imitation of the products or services marketed under the reputed mark, where the use of his sign would cause harm to the distinctive character or the repute of the latter, or where it would adversely affect the functions of the reputed mark. ${ }^{93}$

To rub salt into the wound, the concept of a "due cause" must be interpreted "restrictively," 94 albeit accounting for any subjective interest of the applicant in using a sign that calls to mind the mark with a reputation. ${ }^{95}$

However, there has recently been a softening of this approach on the part of the UK courts. In the PlanetArt decision, the court held that the examination of due cause must take into account "the circumstances of the trade" and should not be so strict that the applicant must prove that "there is no practical alternative at all to the use of the sign in question." 96

\subsection{The Question of Substitutes: Is There Really no Alternative to Brand Products?}

To quote Justice Fancourt in Sazerac, "it is axiomatic that strong and direct competition is not taking unfair advantage, nor is there any tort of copying or positioning one's brand to meet an identified demand." 97

Certainly, trade marks are recognized as a legitimate restriction of the freedom of commerce $^{98}$ and, arguably, in principle, competitors can and should invest their own efforts into conceiving and promoting an original sign under which they can market their goods and services. ${ }^{99}$

Nevertheless, trade mark law, in so far as it protects the investment function of a reputed mark, does not for as much shield the proprietor from all competition, even if this means that he must work harder in order to preserve this reputation. ${ }^{100}$

\footnotetext{
91 Opinion of Advocate General Sharpston in Kenzo (C-85/16 P and C-86/16 P) [2017] EU:C:2017:950, point 38 .

92 Leidseplein (supra note 90), para. 46; Kenzo (supra note 24), para. 91.

93 Interflora (supra note 7), para. 91.

94 Case T-201/14 The Body Shop International plc v. OHIM [2016] EU:T:2016:148, para. 65; Oreo (supra note 26), para. 133.

95 Leidseplein (supra note 90), para. 45.

96 PlanetArt (supra note 56), para. 43 per HHJ Alexander QC.

97 Sazerac (supra note 45), para. 91.

98 Bohaczewski (supra note 29), p. 857.

99 Davies (supra note 52), p. 370; Anemaet (supra note 9), p. 192. See also Case BL O/227/19 Airsorted Limited v. Airbnb, Inc [2019], para. 76.

100 Interflora Inc \& Anor v. Marks and Spencer Plc (Rev 1) [2014] EWCA Civ 1403, paras. 98 and 100 per Kitchin J. See also Interflora (supra note 7), para. 64; Interflora Inc \& Anor v. Marks and Spencer Plc \& Anor [2013] EWHC 1291 (Ch), para. 273 per Arnold J.
} 
As recalled by the Advocate General in Interflora, "in the case of identical or similar goods or services, the purpose of presenting a commercial alternative to the goods or services protected by a trade mark with a reputation should count as due cause." ${ }^{101}$ This may apply even where the applicant intentionally uses a sign similar to a mark with a reputation with a view to taking advantage of its distinctive character and repute. ${ }^{102}$

Indeed, the use of a similar sign is sometimes deemed to be ineluctable. Due cause may therefore be found where the applicant demonstrates that he cannot reasonably be required to abstain from using such a sign as, for example, it would be made necessary for the marketing of his products. ${ }^{103}$ This is especially true where the sign makes use of descriptive terms or elements in order to indicate the type of goods or services offered by the applicant under the mark applied for. ${ }^{104}$

In fact, most substitute products will, inherently, be somewhat descriptive, the description in question usually pertaining to the trade-marked brand product to which they provide an alternative. ${ }^{105}$

However, it is nonetheless reasonable to require that businesses ensure that the presentation and marketing of their products or services are sufficiently different from those of other undertakings, "especially where they are competing in the same market for the same customers" such that, failing to do so, the applicant cannot, in these circumstances, rely on the use of descriptive terms as due cause. ${ }^{106}$

The use of descriptive terms is, however, essential for the development of alternatives; and, as recognized by the courts, alternatives constitute, in principle, a "due cause". ${ }^{107}$ Consequently, to allow the owner of a mark with great reputation to monopolize descriptive elements, verbal or figurative, pertaining to his brand would undoubtedly have suppressive effects on legitimate competition. ${ }^{108}$

Moreover, as pointed out by Lord Justice Jacob in Reed, the average consumer perceives a descriptive element as such and therefore, in principle, will not normally associate it with a mark, renowned or not. ${ }^{109}$

The UK courts have recently held that it emerges from the Leidesplein decision that, where the opposition is "largely based on the common use of [descriptive]

\footnotetext{
101 Opinion of Advocate General Jääskinen in Interflora (supra note 9), point 99.

102 Specsavers (supra note 24), para. 141 per Kitchin LJ, regarding the use of keywords for advertising alternative products.

103 Case T-21/07 L'Oréal SA v. OHIM [2009] EU:T:2009:80, para. 43. See also Case R 1142/2005-2 MARIE CLAIRE (fig.) / MARIE CLAIRE et al. (15 June 2009), para. 128.

104 See, for example, PlanetArt (supra note 56), para. 186. Cf. EUIPO Guidelines (supra note 4), Sec. 5, 1215.

105 Cf. Blythe (supra note 2), p. 757.

106 PlanetArt (supra note 56), para. 133 per HHJ Alexander QC.

107 Interflora (supra note 7), para. 91. See also Specsavers (supra note 24), paras. 141 and 154 per Kitchin J.

108 Kunstadt (supra note 10), p. 455; Martin Senftleben (2009), p. 59. See also L'Oreal SA v. Bellure NV [2010] EWCA Civ 535, para. 16 per Jacob J.

109 Reed Executive plc v. Reed Business Information Ltd [2004] EWCA Civ 159, paras. 83-84.
} 
elements," it will be easier for the applicant to prove due cause as regards the use of those elements. ${ }^{110}$ In fact, the use of a descriptive term "has the impact of somewhat downgrading the significance of conceptual similarity [...] at least in so far as the mark is descriptive of the goods and services in question." 111

The logic is thus: the existence of a link between the marks at issue is certainly indispensable, but not sufficient to establish the taking of an unfair advantage or risk thereof. $^{112}$

Unfortunately, in recent cases, this principle seems to have been ignored, at the expense of legitimate competition.

In a case reminiscent of the "smell-alike" L'Oréal decision pertaining to cheap alternatives to luxury perfumes, ${ }^{113}$ the General Court found that, in Oreo, the fact that the representation of two sandwich cookies in the mark applied for was descriptive of the product did not negate that the "overall impression produced by the mark" was such that, because of the association it created with the mark with a reputation, it took unfair advantage of the latter. ${ }^{114}$ Evidently, as the exclusion of a likelihood of confusion has no effect on the finding of a risk of parasitism, ${ }^{115}$ the fact that the brand name of the applicant ("Gullón") and its product ("Twins") were made clear was irrelevant. ${ }^{116}$

On the contrary, like in $L^{\prime}$ Oréal, ${ }^{117}$ the choice of very similar packaging arguably belied the applicant's intention to take advantage of the reputed "Oreo" mark. However, as previously discussed, intention is not necessarily conclusive as to the taking of unfair advantage. Besides, as pointed out in PlanetArt, emulating successful marketing strategies should not be equated to "the more specific intention to benefit from the reputation and goodwill of the registered trade mark." 118

The General Court found that the applicant was free to register the representation of a generic sandwich cookie, and therefore that there was no monopolization of a mark consisting of "the packaging of the product and including the image of the product itself." 119 However, the cookie thereby represented could not "imitate and approximate the design" of the black and white Oreo biscuit. ${ }^{120}$ In summary, the applicant was free to register a competing mark for its product - which was

\footnotetext{
110 PlanetArt (supra note 56), para. 44 per HHJ Alexander QC.

111 Ibid. para. 29.

112 See, for example, Intel (supra note 33), para. 32; L'Oréal SA v. Bellure NV (supra note 27), para. 37; Iron \& Smith (supra note 19), para. 31; Case T-144/19 Kludi GmbH \& Co. KG v. EUIPO [2020] EU:T:2020:404, para. 156.

113 L'Oréal SA v. Bellure NV (supra note 27).

114 Case T-677/18 Galletas Gullón, SA v. EUIPO [2020] EU:T:2020:229 (Oreo), paras. 45 and 49.

115 Ibid. para. 128. See also Adidas (supra note 24), para. 29; L'Oréal SA v. Bellure NV (supra note 27), para. 36.

116 Ibid. paras. 128 and 135.

117 L'Oréal SA v. Bellure NV (supra note 27), paras. 46-48.

118 PlanetArt (supra note 56), paras. 38 and 118 per HHJ Alexander QC.

119 Oreo (supra note 114), para. 129.

120 Ibid.
} 
recognized as being a substitute and thus "interchangeable and competitive" ${ }^{121}$ - so long as it didn't remotely recall the product to which it would present an alternative.

Talk about the pot calling the biscuit black.

In the UK, the High Court came to the same conclusion in the recent "lookalike" Red Bull case, concerning the competing energy drink "Big Horn." 122

The reasoning common to both of these recent cases was, excuse the pun, hard to swallow.

Chiefly, the reasons given for the existence of a link between the marks at issue $^{123}$ were reproduced for the purposes of establishing the taking of unfair advantage by the applicant. This is however in complete contradiction with the aforementioned settled case-law according to which the existence of a link does not alone suffice to prove the taking of unfair advantage. ${ }^{124}$

Likewise, in both cases it was decisive that the applicants' products would be sold side-by-side in the same retail outlets - generally in supermarkets as they were, in both cases, mass consumption goods - and on a self-service basis, such that they were considered to be direct competitors of the brand names. ${ }^{125}$ For both courts, it followed that, as the products marketed under the later marks would be perceived as substitutes by consumers, the latter would, inferentially, be inclined to project them the same characteristics as the brand products and, consequently, the later marks applied for would unduly benefit from the exceptional reputation and highly distinctive character of those earlier marks. ${ }^{126}$

However, as pointed out by Lord Justice Jacob in L'Oréal, “consumers are not stupid" such that they will not project the reputed qualities of the original onto the copy, but "will see it for what it is and no more."127

Quite the opposite; consumers will tend to view "-alike" products more unfavourably in comparison to the originals, especially quality-wise. ${ }^{128}$ The impetus behind the success of brand products is the category of consumers that solely desire to "buy into" the image that they portray, ${ }^{129}$ and this desire is simply not quenched by purchasing cheaper alternatives. For example, Coca Cola is often sold next to imitator products in red and white packaging; but many claim that these substitutes just don't "taste like the real thing." 130

\footnotetext{
121 Ibid. para. 112.

122 Red Bull GmbH v. Big Horn UK Limited and Others [2020] EWHC 124 (Ch), see especially para. 38 per Bacon DJ.

123 Ibid. paras. 10, 29-32 and 34-38 per Bacon DJ; Oreo (supra note 114), paras. 106 and 112-117.

124 See (supra note 112).

125 Red Bull (supra note 122), para. 37; Oreo (supra note 114), para. 125. See also British Sugar plc $v$. James Robertson \& Sons Ltd [1996] RPC 281, paras. 296-297.

126 Red Bull (supra note 122), para. 38; Oreo (supra note 114), para. 126.

127 L'Oreal SA \& Ors v. Bellure NV \& Ors [2007] EWCA Civ 968, para. 63.

128 Cf. F. van Horen (2010), p. 133.

129 Davies (supra note 52), p. 373; Blythe (supra note 2), p. 754.

130 Tony Naylor, "Cola taste test: the best and worst alternatives to the 'real thing'" (14 September 2016), The Guardian <https://www.theguardian.com/lifeandstyle/2016/sep/14/cola-taste-test-best-andworst-alternatives-coca-cola $>$ accessed 5 April 2021.
} 
That being said, it must be recalled that the provisions on the taking of unfair advantage target the misappropriation of investments and punish the fact that an advantage has been unjustifiably gained. Hence, the vicious circle of where unfairness ends and due cause begins.

\section{Conclusion}

The Brexit Agreement perpetuates the extensive protection existing under EU legislation. ${ }^{131}$

Nevertheless, it is warranted to question the legitimacy of these provisions, unbridled by the moderative exigence of actively proving harm or a potential thereof to the mark, and thereby to the interests of its owner.

Indeed, if it is consistently recognized that trade marks do not give their proprietor a monopoly in the market he operates in, ${ }^{132}$ sometimes this postulate appears to be not much more than mere ink on paper. The provisions on unfair advantage effectively enable the proprietor to monopolize his investments, despite their physical embodiment being exhausted in the goods and services that he offers and makes freely available on the open market.

By excluding legitimate alternatives, there is great potential for the owner of a mark with a reputation to gain monopoly rents without justification, for example, in the name of consumer protection (namely from confusion). ${ }^{133}$ Conversely, as the proprietor does not feel obliged to further invest in the quality or breadth of his line of products or services in order to stay abreast of competition, not only freedom of commerce but also consumer choice suffers.

However, as we have seen, the UK courts appear to be embarking on a more competition-oriented approach when applying the provisions on the taking of unfair advantage. How they will continue to evolve post-Brexit remains to be seen; the future looks nonetheless promising.

Funding Open Access funding provided by the IReL Consortium.

Open Access This article is licensed under a Creative Commons Attribution 4.0 International License, which permits use, sharing, adaptation, distribution and reproduction in any medium or format, as long as you give appropriate credit to the original author(s) and the source, provide a link to the Creative Commons licence, and indicate if changes were made. The images or other third party material in this article are included in the article's Creative Commons licence, unless indicated otherwise in a credit line to the material. If material is not included in the article's Creative Commons licence and your intended use is not permitted by statutory regulation or exceeds the permitted use, you will need to obtain permission directly from the copyright holder. To view a copy of this licence, visit http:// creativecommons.org/licenses/by/4.0/.

\footnotetext{
131 Agreement on the Withdrawal of the United Kingdom of Great Britain and Northern Ireland from the European Union and the European Atomic Energy Community [2020], Treaty Series No 3, CP 219, vol 1, referring to Art. 9(2)(c) of the EUTMR (supra note 22) and Art. 5(3)(a) of the TMD (supra note 20). 132 Fhima (supra note 12), p. 490; Davies (supra note 52), p. 379. See also Sazerac (supra note 45), para. 110.

133 Cf. Glynn S. Lunney Jr (1999), pp. 367-487.
} 


\section{References}

Anemaet L (2020) The many faces of the average consumer: is it really so difficult to assess whether two stripes are similar to three? IIC 51(2):187-213. https://doi.org/10.1007/s40319-020-00907-0

Bently L, Sherman B (2014) Intellectual property law, 4th ed. OUP

Blythe A (2012) Attempting to define unfair advantage: an evaluation of the current law in light of the recent European decisions. EIPR 34(11):754-761

Bohaczewski M (2020) Conflicts between trade mark rights and freedom of expression under EU trade mark law: reality or illusion? IIC 51(7):856-877. https://doi.org/10.1007/s40319-020-00964-5

Davies C (2013) To buy or not to buy - the use of a trade mark as a communication tool rather than as a link between a product and its source - a further consideration of the concept of dilution. EIPR 35(7):373-382

Fhima I (2012) The role of legitimacy in trade mark law. Curr Leg Probl 65(1):489-527. https://doi.org/ 10.1093/clp/cus014

Klerman D (2006) Trademark dilution, search costs, and naked licensing. Fordham L Rev 74(4):1759-1773

Kunstadt R (2008) Trade marks: not just for the rich and famous. JIPLP 3(7):451-456. https://doi.org/10. 1093/jiplp/jpn085

Lunney G Jr (1999) Trademark monopolies. Emory L J 48(2):367-487

Mostert F, Baeumer L (1997) Famous and well-known marks: an international analysis, 6th ed. Butterworths

Schechter F (1927) The rational basis of trademark protection. Harvard L Rev 40(6):813-833

Senftleben M (2009) The trademark tower of Babel. IIC 40(1):45-77

Publisher's Note Springer Nature remains neutral with regard to jurisdictional claims in published maps and institutional affiliations. 